\title{
Desain Kendali Optimal Konsumsi Energi Pada Sistem Mobil Listrik Untuk Model Sistem Linier
}

\author{
Rina Ristiana ${ }^{1}$, Arief Syaichu Rohman ${ }^{2}$, Ary Setijadi Prihatmanto ${ }^{3}$, Carmadi Machbub ${ }^{4}$ \\ ${ }^{1}$ UPT. Balai Pengembangan Instrumentasi - LIPI \\ Jl. Sangkuriang Gedung 30 Kompleks LIPI Bandung \\ ${ }^{2,3,4}$ Sekolah Teknik Elektro dan Informatika - ITB \\ Jl. Ganesha No. 10 Bandung \\ e-mail: ${ }^{1}$ rina005@lipi.go.id, ${ }^{2}$ arief@1skk.ee.itb.ac.id, ${ }^{3}$ ary.setijadi@gmail.com, \\ ${ }^{4}$ carmadi@1skk.ee.itb.ac.id
}

\begin{abstract}
Abstrak - Telah dirancang metoda kendali optimal konsumsi energi pada sistem mobil listrik untuk model sistem linier dengan menggunakan metoda calculus of variations. Sebuah representasi konseptual sistem nyata dari mobil listrik digambarkan dalam bentuk model dan persamaan matematik. Model sistem mobil listrik terdiri dari dinamika kendaraan dan dinamika motor listrik. Berdasarkan model sistem tersebut dapat dirumuskan tiga alternative indeks kinerja dan metoda hokum kendali. Sebagai salah satu contoh kasus, dipilih persamaan indeks kinerja alternative 1 untuk mendapatkan alternative metode kendali optimal. Hasil akhir yang diinginkan didasarkan pada suatu solusi konsumsi energi minimum dengan memilih vector kendali yang masih memenuhi constraint dan masih menjamin kestabilan sistem.
\end{abstract}

Kata Kunci: active safety, vehicle dynamics control, bicycle model, vehicle stability

\section{Pendahuluan}

Mobil listrik merupakan kendaraan menggunakan energi listrik sebagai sumber tenaganya. Mobil listrik dikenal dengan kendaraan ramah lingkungan dan tidak memproduksi emisi gas buang, namun mobil listrik memiliki keterbatasan energi yang tersimpan dalam baterai [1]. Dengan asumsi penggunaan baterai yang sudah ada dan energinya yang terbatas, maka perlu adanya strategi pemakaian energi secara optimal dan efisien, hal ini menjadikan pentingnya optimasi energi.

Optimasi energi pada mobil listrik meliputi seberapa optimal konsumsi energi untuk menghasilkan tenaga gerak, seberapa efisien energi recovery yang dihasilkan untuk digunakan mengisi baterai dan seberapa jauh jarak tempuh kendaraan dengan energi yang tersedia. Faktanya bahwa kendaraan lebih banyak melakukan pergerakan yang membutuhkan tenaga penggerak, sehingga optimasi konsumsi energi paling penting dalam strategi optimasi energi.

Konsumsi energi adalah besar daya yang digunakan dalam periode waktu tertentu $(E=P . t)$. Dengan asumsi untuk konsumsi energi dalam waktu yang sama $(\Delta t=$ constant $)$, akan mendapatkan pemakaian daya minimum $(P=\downarrow \downarrow)$ jika diinginkan konsumsi energi minimum $(E=$ $\downarrow \downarrow)$. Seberapa kecilkah pemakaian daya yang diinginkan agar tercapai kondisi konsumsi energi yang optimal. Hal ini dapat dianalisa dari beberapa bentuk daya, sehingga didapatkan variablevariable yang harus diperhitungkan, antara lain arus, dan kecepatan.

Beberapa penelitian-penelitian yang telah dilakukan untuk optimasi energi, diantaranya; Sabooshi, dkk, 2009, dan Xinxai, dkk, 2015, mendesain strategi optimal berkendara (eco-driving)

TELKA, Vol.4, No.1, Mei 2018, pp. 01 10

ISSN (e): 2540-9123

ISSN (p): 2502-1982 
dengan kendali optimal kecepatan kendaraan [2], [3]. Abdelkader dkk, 2009, mengembangkan metoda untuk mencari strategi kendali dan menghitung konsumsi energi minimal dengan teknik pengendalian arus baterai [4]. Qin Yan dkk, 2014, memodelkan algoritma optimasi konsumsi energi dengan menentukan profile kecepatan kendaraan [5]. Dongbin, dkk, 2014, mendesain strategi kendali optimal hemat energi dengan pengendalian kecepatan motor PMSM [6]. Patrick, dkk, 2015, dan Xiaohai, dkk, 2014, mendesain strategi hemat energi berkendara dengan implementasi advanced driver assistance system (ADAS). ADAS menggambarkan persepsi percepatan dari perilaku pengemudi berupa visual dan sistem sensor [7], [8]. Schwickart, dkk, 2015 , mendesain model optimisasi yang mencakup model perpindahan kendaraan dalam bentuk energi kinetic.

Terdapat dua permasalahan pokok dalam merancang konsumsi energi optimal, yaitu optimal energi berdasarkan profile kecepatan dan optimal energi berdasarkan pengendalian kecepatan atau arus. Dalam makalah ini dibahas optimal energi berdasarkan pengendalian kecepatan sehingga diperlukan kendali optimal kecepatan untuk konsumsi energi yang minimum.

Dalam makalah ini akan dipaparkan dinamika sistem mobil listrik sederhana pada bagian 2, menggambarkan model sistem mobil listrik untuk sistem linier pada bagian 3, merancang indeks kinerja dan hukum kendali optimal pada bagian 4, dan kesimpulan pada bagian 5 .

\section{Dinamika Sistem Mobil Listrik}

Dinamika sistem mobil listrik membahas tentang persamaan matematis sistem mobil listrik untuk memahami sifat dan karakteristik dinamika sistem dalam rangka peningkatan performa sistem. Sistem mobil listrik didefinisikan sebagai kombinasi dari beberapa komponen yang dimiliki mobil listrik yang saling keterkaitan dan mendukung suatu fungsi tertentu. Komponenkomponen sistem mobil listrik seperti yang dapat dilihat pada Gambar 1, terdiri dari baterai, converter daya, motor listrik, transmisi dan roda [9], [10], [11], [12].

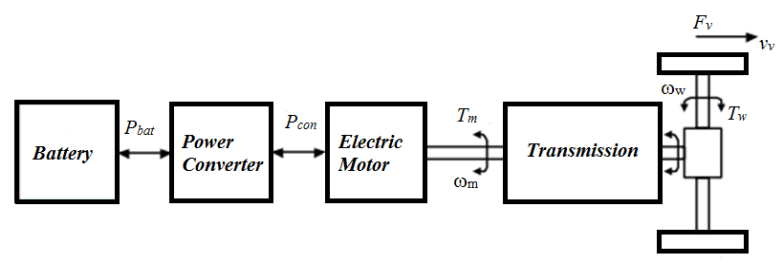

Gambar 1. Dinamika Sistem Mobil Listrik

Untuk menggambarkan karakteristik sistem mobil listrik yang sederhana, dinamika sistem mobil listrik terdiri dari dinamika kendaraan longitudinal dan dinamika motor listrik.

\subsection{Dinamika Kendaraan Longitudinal}

Dari semua pergerakan yang dimilikinya, kendaraan lebih sering melakukan pergerakan longitudinal dalam melakukan manuvers-nya, maka dari itu gerak kendaraan longitudinal memiliki konsumsi energi paling banyak. Makalah ini khusus membahas optimasi energi saat kendaraan melakukan gerak longitudinal. Gerak longitudinal kendaraan adalah kemampuan kendaraan bergerak melaju kearah depan (maju). Ketika kendaraan bergerak longitudinal, terdapat gaya-gaya yang bekerja pada kendaraan, antara lain gaya traksi $\left(\mathrm{F}_{\mathrm{t}}\right)$, gaya resistansi $\left(\mathrm{F}_{\mathrm{rt}}\right)$ dan gaya akselerasi $\left(F_{a}\right)$ seperti yang dapat dilihat pada Gambar 2 [13], [14].

Gaya traksi adalah gaya dorong (gaya penggerak) kendaraan sehingga kendaraan dapat bergerak. Kinerja gaya traksi kendaraan dapat dijelaskan dari pemindah daya (powertrain) seperti terlihat pada Gambar 1. Dapat dijelaskan bahwa torka motor mekanik merupakan tenaga penggerak yang mengalir melalui powertrain sampai ke porors roda. Torka yang bekerja pada roda kendaraan adalah sebanding perkalian torka motor terhadap perbandingan transmisi $\left(\eta_{t} n_{t}\right)$ dengan gearbox $\left(\eta_{g} n_{g}\right)$, dapat dituliskan sebagai berikut : [13], [15]. 


$$
T_{w}(t)=\eta_{t} n_{t} \eta_{g} n_{g} T_{m}(t)
$$

Untuk kecepatan roda kendaraan dapat dituliskan:

$$
\omega_{w}(t)=\frac{1}{n_{t} n_{g b}} \omega_{m}(t)
$$

Gaya traksi sebanding torka roda $\left(\mathrm{T}_{\mathrm{w}}\right)$ terhadap radius $\operatorname{roda}\left(\mathrm{r}_{\mathrm{w}}\right)$;

$$
F_{t}(t)=\frac{T_{w}(t)}{r_{w}}
$$

Persamaan kecepatan kendaraan;

$$
v_{v}(t)=r_{w} \omega_{w}(t)
$$

Gaya resistance kendaraan merupakan total dari aerodynamics drag forces $\left(\mathrm{F}_{\mathrm{d}}\right)$, grading resistance $\left(\mathrm{F}_{\mathrm{g}}\right)$ dan rolling resistance $\left(\mathrm{R}_{\mathrm{x}}\right)$, dapat dituliskan sebagai berikut;

$$
F_{r t}(t)=C_{R x} m_{v} g \cos \theta+1 / 2 \rho C_{d} A_{f}\left(v_{v}(t)\right)^{2}+m_{v} g \sin \theta
$$

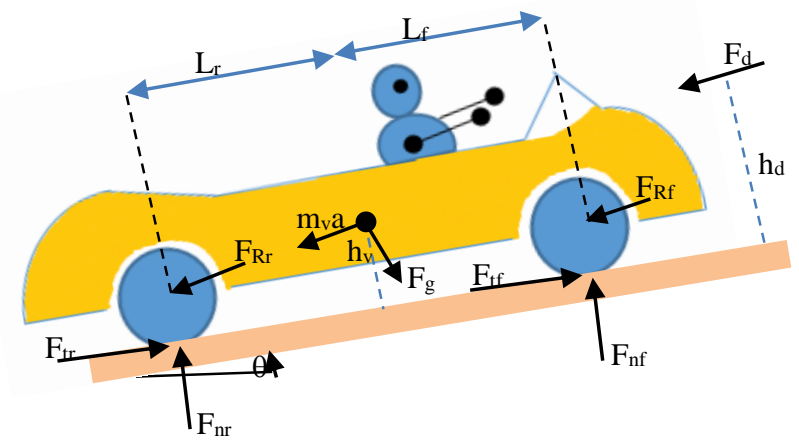

Gambar 2. Dinamika Kendaraan Longitudinal

Gaya akselerasi merupakan gaya traksi $\left(\mathrm{F}_{\mathrm{t}}\right)$ dikurangi total gaya resistansi kendaraan $\left(\mathrm{F}_{\mathrm{rt}}\right)$, berdasarkan hukum kedua Newton dapat dituliskan sebagai berikut; [16], [14].

$$
\delta m_{v} a_{v}(t)=\sum F_{t}(t)-\sum F_{r t}(t)
$$

Dengan $\mathrm{m}$ adalah mass kendaraan, $\mathrm{a}_{\mathrm{v}}$ adalah percepatan kendaraan longitudinal $\left(a_{v}(t)=\right.$ $\left.\frac{d v_{v}(t)}{d t}\right)$ dan $\delta(\mathrm{t})$ adalah faktor mass inertia $\left(\delta(t)=1+\frac{J_{w}}{m_{v} r_{w}{ }^{2}}+\frac{J_{m} n_{g}{ }^{2}(t)}{m_{v} r_{w}{ }^{2}}\right)$, dengan $\mathrm{J}_{\mathrm{w}}=$ inersia roda, $\mathrm{J}_{\mathrm{m}}=$ inersia motor listrik dan $\mathrm{n}_{\mathrm{g}}=$ gear ratio. Substitusikan pers (3) dan pers (5) ke pers (6), persamaan menjadi :

$$
\delta m_{v} \frac{d v_{v}(t)}{d t}=T_{w}(t) \frac{1}{r_{w}}-\left(C_{R x} m_{v} g \cos \theta+1 / 2 \rho C_{d} A_{f}\left(v_{v}(t)\right)^{2}+m_{v} g \sin \theta\right)
$$

\subsection{Dinamika Motor Listrik}

Motor listrik merupakan sebuah perangkat elektromagnetik yang mengubah energi listrik menjadi energi mekanik. Motor listrik dengan konsumsi energi yang rendah dan efisiensi lebih 
tinggi adalah motor listrik BLDC, sehingga cocok untuk digunakan pada mobil listrik khususnya mobil listrik nasional (Molina) ITB.

Motor listrik BLDC memiliki tiga kumparan stator dan magnen permanen pada rotor, seperti yang dapat dilihat pada Gambar 3. Motor listrik BLDC menggunakan sumber tegangan DC sebagai sumber energi utamanya. Motor dideskripsikan memiliki tegangan tiga fasa. Tujuan dari pemberian tegangan tiga fasa pada stator adalah menciptakan medan magnet putar stator untuk menarik magnet rotor [17], [18].

Dengan asumsi arus induksi pada rotor dan harmonic medan magnet pada stator diabaikan, juga iron losses dan stray losses pada motor diabaikan, serta flux linkage per fasa sebanding dengan $1 / \pi$, hal ini berarti tidak ada perubahan flux linkages pada setiap fasanya sehingga setiap tegangan fasa simetrik (sama) dan tidak ada perubahan posisi rotor. Dengan hal tersebut kinerja motor listrik BLDC seperti halnya motor DC, namun motor listrik BLDC memiliki tiga kutub yang dapat dipakai bergiliran dengan tegangan line-to-line [19], [20].

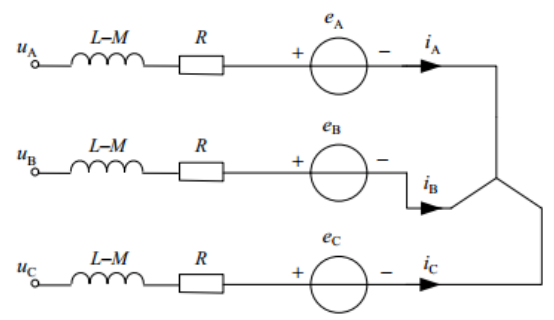

Gambar 3. Rangkaian motor listrik BLDC

Persamaannya dapat dituliskan sebagai berikut ;

$$
\begin{aligned}
& V_{a b}(t)=R_{s} i_{a}(t)+L-M \frac{d i_{a}(t)}{d t}+M-L \frac{d i_{b}(t)}{d t}+e_{a b}(t) \\
& V_{b c}(t)=R_{s} i_{b}(t)+L-M \frac{d i_{b}(t)}{d t}+M-L \frac{d i_{c}(t)}{d t}+e_{b c}(t) \\
& V_{c a}(t)=R_{s} i_{c}(t)+M-L \frac{d i_{a}(t)}{d t}+L-M \frac{d i_{c}(t)}{d t}+e_{c a}(t)
\end{aligned}
$$

Analisa motor listrik dari aspek kelistrikan, [21]

Tegangan motor dengan back emf $\left(e_{m}(t)=k_{e} \omega_{m}(t)\right)$ persamaan dapat dituliskan sebagai berikut

$$
V_{m}(t)=R_{m} i_{m}(t)+L_{m} \frac{d i_{m}(t)}{d t}+k_{e} \omega_{m}(t)
$$

Torka developed electric motor:

$$
T_{\text {dev }}(t)=k_{t} i_{m}(t)
$$

Analisa motor listrik dari aspek mekanik, [22]

Torka motor mekanik

$$
T_{m}(t)=J_{m} \frac{d \omega_{m}(t)}{d t}+b_{m} \omega_{m}(t)
$$

Dengan $\mathrm{J}_{\mathrm{m}}$ adalah momen inersia, $\mathrm{b}_{\mathrm{m}}$ adalah koefisien damping [Nms], dan torka motor merupakan torka develop motor listrik dikurangi dengan torka beban $\left(\mathrm{T}_{\mathrm{L}}\right)$, persamaan dapat dituliskan sebagai berikut ;

$$
T_{m}(t)=T_{d e v}(t)-T_{L}(t)
$$




\section{Pemodelan Sistem Mobil Listrik}

Pemodelan sistem mobil listrik bertujuan untuk mengembangkan sebuah representasi konseptual sistem nyata dari mobil listrik dalam bentuk model dan persamaan matematik. Model matematik kemudian harus diuji untuk melihat sejauh mana model itu dapat digunakan untuk menjawab pertanyaan yang mungkin timbul berkaitan dengan sistem yang digambarkan. Tujuan akhir dari pemodelan sistem mobil listrik adalah menentukan variable input, variabel keadaan, variable kendali dan persamaan keadaannya dengan variable output yang diinginkan berupa kecepatan motor. Gambar 4 menjelaskan blok diagram model sistem mobil listrik dalam persamaan matematik.

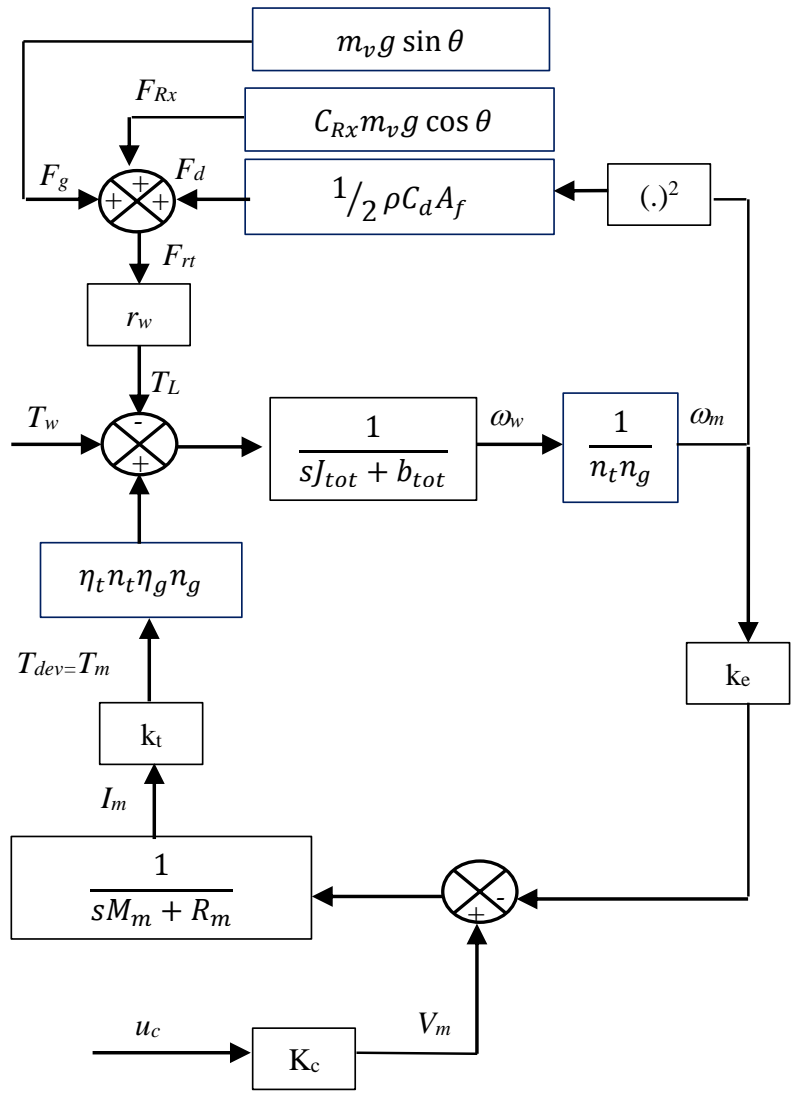

Gambar 4. Blok Diagram Model Sistem Mobil Listrik

Berikut langkah-langkah pemodelan sistem mobil listrik berawal dari gaya longitudinal kendaraan yang digambarkan oleh pers (7). Pada makalah ini perancangan model system yang linier atau model listrik yang paling sederhana, dengan asumsi drag aerodynamic force diabaikan, dan substitusi pers (4) ke pers (7), selanjutnya didapatkan persamaan torka roda kendaraan sebagai berikut;

$T_{w}(t)=\delta m_{v} r_{w}^{2} \frac{d \omega_{w}(t)}{d t}+C_{R x} m_{v} r_{w} g \cos \theta+m_{v} r_{w} g \sin \theta$

Substitusikan pers (1) dan pers (2) ke pers (12), persamaan untuk torka motor dapat dituliskan;

$T_{m}(t)=\frac{1}{\eta_{t} n_{t} \eta_{g} n_{g}}\left(\delta m_{v} r_{w}{ }^{2} \frac{1}{n_{t} n_{g b}} \frac{d \omega_{m}(t)}{d t}+C_{R x} m_{v} r_{w} g \cos \theta+m_{v} r_{w} g \sin \theta\right)$

Dalam keadaan steady state $T_{m}(t)=T_{\text {dev }}(t)$, maka pers (11) dapat dituliskan $T_{m}(t)=$ $-T_{L}(t)$, dengan torka load $\left(T_{L}(t)\right)$ adalah torka load motor $\left(T_{L}(t)=b_{m} \omega_{m}(t)\right)$. Dengan asumsi $J_{\text {tot }}=\delta m_{v} r_{w}{ }^{2}$ dan $b_{\text {tot }}=\eta_{t} n_{t}{ }^{2} \eta_{g} n_{g}{ }^{2} b_{m}$, didapat persamaan seperti berikut; 


$$
\frac{d \omega_{m}(t)}{d t}=-\frac{b_{t o t}}{J_{t o t}} \omega_{m}(t)-\frac{1}{J_{t o t}} n_{t} n_{g b} C_{R x} m_{v} r_{w} g \cos \theta-\frac{1}{J_{t o t}} n_{t} n_{g b} m_{v} r_{w} g \sin \theta
$$

Dapat dituliskan kembali pers (8), seperti persamaan berikut :

$$
\frac{d i_{m}(t)}{d t}=-\frac{k_{e}}{L_{m}} \omega_{m}(t)-\frac{R_{m}}{L_{m}} i_{m}(t)+\frac{1}{L_{m}} V_{m}(t)
$$

Dari pemodelen sistem tersebut, dapat digambarkan model sederhana dari mobil listrik seperti yang dapat dilihat pada Gambar 3. Dari model sistem ini dapat ditentukan variabel state dengan $x_{1}=\omega_{m}(t), x_{2}=i_{m}(t), \dot{x}_{1}=\frac{d \omega_{m}(t)}{d t}$ dan $\dot{x}_{2}=\frac{d i_{m}(t)}{d t}$. Variable output berupa $y=$ $\omega_{m}=x_{1}$, serta control variable samadengan $u_{c}=V_{m}$.

Dari model sistem juga didapat bentuk state space yang merupakan sistem linier dengan persamaan dituliskan sebagai berikut:

Dengan :

$$
\dot{x}=A x+B u_{c}+d_{L}
$$

$$
\begin{aligned}
& \dot{x}_{1}=-\frac{b_{t o t}}{J_{t o t}} x_{1} \\
& \dot{x}_{2}=-\frac{k_{e}}{L_{m}} x_{1}-\frac{R_{1}}{L_{m}} x_{2}+\frac{1}{L_{m}} u_{c} \\
& d_{L}=-\frac{1}{J_{t o t}} n_{t} n_{g b} C_{R x} m_{v} r_{w} g \cos \theta-\frac{1}{J_{t o t}} n_{t} n_{g b} m_{v} r_{w} g \sin \theta
\end{aligned}
$$

\section{Desain Kendali Optimal}

Keberadaan controller dalam sebuah sistem kendali mempunyai kontribusi yang besar terhadap perilaku sistem. Pada prinsipnya karakteristik sistem harus diterima sebagaimana adanya, sehingga perubahan perilaku sistem hanya dapat dilakukan melalui penambahan suatu subsistem yaitu controller. Masalah umum dalam sistem kendali adalah pencapaian spesifikasi performansi dan kecepatan respon tersebut dicapai.

Metode kendali optimal adalah suatu konsep optimasi sistem kendali yang memperhitungkan pemilihan indeks kinerja serta desain kendali optimal dalam batas-batas kendala (constraint) fisik. Indeks kinerja didefinisikan sebagai suatu fungsi yang nilainya menunjukan seberapa baik performansi sistem yang sebenarnya mendekati performansi yang diinginkan. Metode kendali optimal dapat juga dikatakan suatu metode kendali yang pencarian solusinya didasarkan pada usaha untuk meminimumkan atau memaksimalkan suatu fungsi indeks kinerja dengan memilih vector kendali dan masih memenuhi constraint.

Dalam kasus mobil listrik, desain kendali optimal bertujuan untuk meminimalkan konsumsi energi, dengan energi yang tersimpan dalam baterai dimasukkan dalam constraint. Setiap problem optimasi memiliki dua bagian penting, yaitu indeks kinerja (index performance) dan batas kendala (constraints). Berdasarkan pada model sistem yang telah dirancang, indeks kinerja dapat dirumuskan dengan beberapa alternative pilihan sebagai berikut, dengan mengacu pada indeks kinerja konsumsi energy yang umum digunakan adalah :

$$
E_{c}=\int_{t_{0}}^{t_{f}} P d t
$$


- Alternative 1

Asumsi daya sebanding dengan tegangan beban kuadrat dibagi resistansi beban $(P=$ $V_{m}^{2} / R_{m}$ ), diketahui bahwa $V_{m}=u_{c} k_{c}$, sehingga persamaan daya didapat $P=u_{c}{ }^{2} \frac{k_{c}{ }^{2}}{R_{m}}$ dan indeks kinerja dapat dirumuskan sebagai berikut;

$$
E_{c}=\int_{t_{0}}^{t_{f}} u_{c}^{2} d t
$$

- Alternative 2

Asumsi bahwa persamaan energi sama dengan persamaan linear quadratic regulator (LQR). Jika menggunakan LQR untuk alternative 1 sebanding dengan bobot matrik $\mathrm{Q}$ dan $\mathrm{R}$ sama dengan nol. Pada alternative 2 ini bobot matrik $\mathrm{Q}$ dan $\mathrm{R}$ diperhitungkan, sehingga indeks kinerja dapat dituliskan sebagai berikut;

$$
E_{c}=\int_{t_{0}}^{t_{f}} x^{T} Q x+u_{c}^{T} R u_{c} d t
$$

- Alternative 3

Asumsi daya sebanding dengan tegangan dikalikan arus $\left(P=V_{m} I_{m}\right)$, dengan $V_{m}=u_{c} k_{c}$ persamaan daya menjadi $P=u_{c} I_{m} k_{c}$ atau dapat dituliskan $P=u_{c} x_{2} k_{c}$, sehingga indeks kinerja dapat dituliskan sebagai berikut;

$$
E_{c}=\int_{t_{0}}^{t_{f}} u_{c} x_{2} d t
$$

Penentuan constraint dapat diklasifikasikan dalam tiga kelompok, antara lain:

- Saturation constraint

Arus motor : $I_{m, \min } \leq I_{b}(t) \leq I_{m, \max }$

Kecepatan motor : $0 \leq \omega_{m}(t) \leq \omega_{m, \max }$

Torka motor : $T_{m, \min }(t) \leq T_{m}(t) \leq T_{m, \max }(t)$

Vector kendali : $-u_{c, m}(t) \leq u_{c}(t) \leq+u_{c, m}(t)$

- Equality constraint

$$
\begin{aligned}
& \frac{d \omega_{m}(t)}{d t}=-\frac{b_{t o t}}{J_{t o t}} \omega_{m}(t)-\frac{1}{J_{t o t}} n_{t} n_{g b} C_{R x} m_{v} r_{w} g \cos \theta-\frac{1}{J_{t o t}} n_{t} n_{g b} m_{v} r_{w} g \sin \theta \\
& \frac{d i_{m}(t)}{d t}=-\frac{k_{e}}{L_{m}} \omega_{m}(t)-\frac{R_{m}}{L_{m}} i_{m}(t)+\frac{1}{L_{m}} V_{m}(t)
\end{aligned}
$$

- Inequality constraint

$E_{c}<E_{b}$

$E_{b}=Q_{n} V_{b}=95 \%$, artinya bahwa $\mathrm{E}_{\mathrm{b}}$ merupakan energi yang tersimpan dalam baterai, dan hanya boleh digunakan $95 \%$ dari energi maksimum yang tersimpan dalam baterai.

Untuk keperluan perancangan hukum kendali optimal, dalam makalah ini menetapkan persamaan indeks kinerja untuk alternative 1 sebagai salah satu studi kasus. Dalam perancangan hukum kendali optimal dengan bentuk indeks kinerja tersebut terdapat beberapa metoda penyelesaian hukum kendali optimal, dalam makalah ini dipilih metoda kendali optimal calculus of variations. Dengan initial condition pada $\mathrm{x}(0)$ dan final condition $\mathrm{x}(T)$, indeks kinerja dituliskan kembali menjadi

State space : $\dot{c}=S c+B u_{c}$

$$
E_{c}=\int_{0}^{T} u_{c}^{2} d t
$$

Dengan $c_{1}=c, c_{2}=\dot{c}, \dot{c}_{1}=c_{2}$ dan $\dot{c}_{2}=u_{c}$ 


$$
c=\left[\begin{array}{l}
c_{1} \\
c_{2}
\end{array}\right], \dot{c}=\left[\begin{array}{l}
\dot{c}_{1} \\
\dot{c}_{2}
\end{array}\right], S=\left[\begin{array}{ll}
0 & 1 \\
0 & 0
\end{array}\right], B=\left[\begin{array}{ll}
0 & 0 \\
0 & 1
\end{array}\right] \text { dan } u_{c}=\left[\begin{array}{l}
0 \\
1
\end{array}\right]
$$

Fungsi Halmiltonian dapat dituliskan :

$$
H=s_{1} c_{2}+s_{2} u_{c}-u_{c}^{2}
$$

Menentukan nilai $\mathrm{s}_{1}, \mathrm{~s}_{2}$ dan $\mathrm{c}_{2}$ :

$$
\begin{gathered}
\dot{s}_{1}=-\frac{\partial H}{\partial c_{1}}=0 \text { dan } \dot{s}_{2}=-\frac{\partial H}{\partial c_{2}}=-s_{1} \\
\dot{c}_{1}=\frac{\partial H}{\partial s_{1}}=c_{2} \text { dan } \dot{c}_{2}=\frac{\partial H}{\partial s_{2}}=u_{c}
\end{gathered}
$$

Didapat nilai : $s_{1}=K_{1}$ dan $s_{2}=K_{2}-s_{1} t=K_{2}-K_{1} t$

Karena $s_{1} c_{2}$ tidak tergantung dari input $u_{c}$, maka persamaan Hamiltonian focus pada

$$
\max _{u_{c}} H\left[s_{2} u_{c}-u_{c}^{2}\right]
$$

Menentukan nilai optimal $u_{c}{ }^{*}$ sebagai berikut

$$
\frac{\partial}{\partial u}\left[s_{2} u_{c}-u_{c}^{2}\right]=0
$$

Dengan $s_{2}-2 u_{c}{ }^{*}=0$, dan nilai optimal didapat $u_{c}{ }^{*}=\frac{s_{2}}{2}$

Jika $\left|s_{2}\right|<2$, maka $u_{c}{ }^{*}=\frac{s_{2}}{2}$, saat $\left|s_{2}\right| \geq 2$, maka $u_{c}{ }^{*}=\operatorname{sign}\left[s_{2}\right]$.

Hasil dari nilai maksimum fungsi Hamiltonian, didapat :

$u_{c}^{*}=\frac{K_{2}}{2}-\frac{K_{1}}{2} t$ untuk $\left|s_{2}\right|<2$

$u_{c}{ }^{*}=\operatorname{sign}\left[s_{2}\right]=\operatorname{sign}\left[K_{2}-K_{1} t\right]$ untuk $\left|s_{2}\right| \geq 2$

Dalam implementasinya, controller pada mobil listrik dapat digambarkan dalam blok diagram seperti yang dapat dilihat pada Gambar 5. Pada blok diagram tersebut sistem ditambahkan subsistem controller sehingga sistem menjadi lup tertutup. Setealah mendapatkan desain kendali optimal untuk selanjutnya dapat dilakukan simulasi dan pengujian terhadap kondisi lingkungan, seperti saat manuver kendaraan pada kondisi jalan menurun atau menanjak dan lain sebagainya.

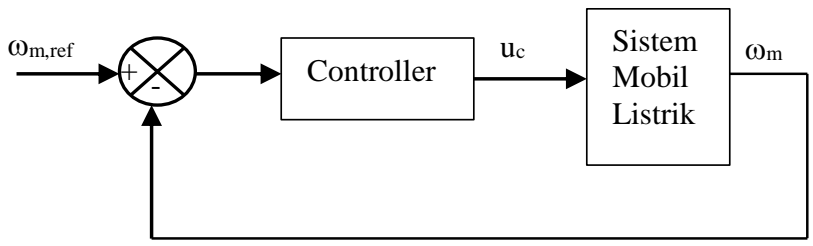

Gambar 5. Blok Diagram Model Sistem Mobil Listrik Lup Tertutup

\section{Kesimpulan}

Dengan merancang sejumlah alternative indeks kinerja dan metoda kendali optimal kecepatan motor yang meminimalkan konsumsi energi tanpa menggunakan dinamika baterai akan didapatkan metoda kendali optimal yang masih menjamin kestabilan system juga pencapaian spesifikasi performansi dan kecepatan respon tersebut dicapai. Model sistem kendaraan bersifat linier sehingga dalam pemilihan kendali dapat berupa kendali linier, serta dalam permodelan system dan perancangan indeks kinerja dan metoda hukum kendali masih sederhana. Selanjutnya dapat dikembangkan model system yang nonlinier dengan pilihan variable-variabel yang tepat 
dapat ditemukan dan diperhitungkan dalam formulasi matematika, menjadikan model sistem semakin komplek begitupun untuk perancangan indeks kinerja dan metoda hokum kendalinya lebih sulit.

\section{Daftar Pustaka}

[1] Boulanger A., G., Chu A., C., Maxx S., Waltz D., L.," "Vehicle Electrification: Status and Issue," in IEEE Proceeding 99(6):1116-1138, 2011.

[2] Saboohi Y., Farzaneh H.," "Model for Developing an Eco-driving Strategy of a Passanger Vehicle Based on the Least Fuel Consumption," Applied Energy, Sciencedirect, pp. pp. 1925-1932, 2009.

[3] Xinxai Wu, Xiozheng He, Guizhen Yu, Harmandayan A, Yunpeng Wang, "Energy Optimal Speed Control for Electric Vehicles on Signalized Arterial," IEEE Transaction on Intelligent Transportation System, vol. Vol. 16, no. No. 5, pp. 2786-2796, 2015.

[4] Abdulkader M., Messine F., Aidene M.,, "On Minimizing the Energy Consumption of an Electrical Vehicle," 2009.

[5] Qin Yan, Bei Zhang, Mladen Kezunovic, "Optimization of Electric Vehicle Movement for Efficient Energy Consumption," IEEE Transaction, pp. 1-6, 2014.

[6] Dongbin L., Ouyang M., Gu J., Li J.,, "Optimal Velocity Control for a Battery Electric Vehicle Driven by Permanent Magnet Synchronous Motors," Mathematical Problems in Engineering, Hindawi Publishing Corporation, pp. pp. 1-14, 2014.

[7] Patrick S., Michael F., Soren H.,, "Subliminal Optimal Longitudinal Vehicle Control for Energy Efficient Driving," in IEEE International Conference on System Manufacture and CYbermatics, p. 3001-3007, 2014.

[8] Xinohai L., Gorges D., Liu S., "Eco-driving Assistance System for Electric Vehicles Based on Speed Profile Optimization," in IEEE Conference on Control Aplication (CCA) part of IEEE Multi conference on System and Control, 2014.

[9] Kirsch, David A., The Electric Vehicle and The Burden of History, Rutgers University Press, pp. 153-162, ISBN 9780813528090, 2000.

[10] K. U. a. N. L, Automotive Control Systems, Springer, 2005.

[11] W. D. McRuer D., "Theory of manual vehicular control," Ergonom, vol. vol.12, pp. pp.599$633,1969$.

[12] M. Raffaele, "Modelling and simulation of the dynamic behavior of the automobile," Thesis of degree, faculty of engineering, Universita degli studi di salerno, 2012.

[13] G. T. D., Fundamentals of Vehicle Dynamics, Society of Automotive Engineers, Inc, 1992.

[14] R. R, Vehicle Dynamics and Control, Springer Verlag, 2006.

[15] J. Y. WONG, Theory of Ground Vehicles, John Wiley \& Sons Ltd, 3rd Edition, 2001.

[16] P. H. B, Tyre and Vehicle Dynamics, Elsevier Science, 2005.

[17] D. Hanselman, Brushless Permanent Magnet Motor Design, Magna Physics Publishing, 2003.

[18] S. Baldrusson, "BLDC Motor Modelling and Control a Matlab/Simulink Implementation," Master Thesis International Masters Program in Electric Power Engineering, Calmer Teknisa Hogskola, 2005.

[19] S. Rambambu, "Modelling and Control of a Brushless DC Motor," THesis National Institute of Technology, 2007.

[20] C.-L. Xia, "Permanent MAgnet Brushless DC Motor Drives and Controls," John Wiley \& Sons Singapore Pte. Ltd, 2012. 
[21] R. Krisnan, Permanent Magnet Synchronous and Brushless DC Motor Drivers, CRC Press, Taylor \& Francis Group, 2010.

[22] M. A. El-Sharkawi, Fundamentals of Electric Drives, Thomson and Learning Academics Resource Center, 2000.

[23] Wissam Dib, Lorenzo Serrao, Antonio Sciarreta, "Optimal Control to Minimize Trip Time and Energy Consumption in Electric Vehicles," ResearchGate, pp. 1-8, 2011.

[24] Tobias Nuesch, Alberto Cerofolini, Giorgio Mancin, Nicolo Cavina, Christopher Onder, Lino Guzzella, "Equivalent Consumption Minimization Strategy for the Control of Real Driving NOx Emissions of a Diesel Hybrid Electric Vehicle," Energies, vol. Vol 7, pp. 3148-3178, 2014.

[25] Sperling, Daniel, Deborah G.,, Two Billion Cars: Driving Toward Sustainability, New York: Oxford Universitu Press, 2009.

[26] Sherry Boschert, Plug in Hybrids: The Cars that will Recharge America, Gabriola Island, Canada: New Society Publishers, pp. 15-28, ISBN 9780865715714, 2006.

[27] Schwicarkt T., Voos H., Hadji-Minaglou J-R., Darouach M., Rosich A.,, "Design and Simulation of a Realtime Implementable Energy-efficient Model Predictive Cruise Controller for Electric Vehicle," Journal of The Franklin Institute, Science Direct, vol. 352, pp. pp. 603-625, 2015.

[28] Raut, Anil K.,, "Role of Electric vehicles in Reducing Air Pollution: A Case of Katmandu, Nepal," The Clean Air Initiative, 01042011.

[29] Quanlu Wang, Mark A. Delucchi, "Impacts of Electric Vehicle on Primary Energy Consumption and Petroleum Displacement," Working Paper, The University of California Transportation Center, University of California at Berkeley, 1991.

[30] Mitchell, William J., Borroni B., Cristopher, Burns, Lawrence D.,, "Clean Smart Energy Supply," in Reinverting The Automobile: Personal Urban Mobility for the 21st Century, The MIT Press, 2010, pp. 85-95.

[31] Michael Dellnitz, Julian Eckstein, KAtrin Flabkamp, Patrick Friedel, Cristian Horenkamp, Ulrich Kohler, Sina Ober-Blobaum, Sebastian Peitz, Sebastian Tiemeyer, "Development of an Intelligence Cruise COntrol using Optimal Control Methods," Science Direct, vol. Procedia Technology 15, pp. 284-294, 2014.

[32] James W. R., Chelsea S., David B. S.,, "Plug in Electric Vehicles: What Role for Washington?," in Geopolitical Implications of Plug in Vehicles ed.1st, The Brookings Institution, 2009, pp. 11-21.

[33] Huang X., Wang J.,, "Nonlinear Model Predictive Control for Improving Energy Recovery for Electric Vehicles suring Regenerative Breaking," in 50th IEEE Conference on Decession and Control-European Control Conference (CDC-ECC), 2011.

[34] "Global EV Outlook: Understanding the Electric Vehicle Landscape to 2020," 2013.

[35] Fereydoon Diba, Ankur Arora, Ebrahim Esmailzadeh, "Optimized Robust Cruise Control SYstem for an Electric Vehicle.," Systems Science \& Control Engineering, vol. Vol 2, pp. 175-182, 2014.

[36] B. David, Sandalow, Plug in Electric Vehicles : What Role for Washington ?, The Booking Instituition, ISBN 987081570305 1, 2009.

[37] B. Schofield, "Model-Based Vehicle Dynamics Control for Active Safety," Thesis Department of Automatic Control Lund University Lund, , 2008. 